\title{
Two cases of severe angio-oedema and rationale for their response to icatibant
}

\author{
Oluwaseun 0 Akinduro, ${ }^{1}$ Vishal Patel, ${ }^{2}$ Tommy Thomas, $^{3}$ Faiz U Ahmad ${ }^{4}$
}

${ }^{1}$ Morehouse School of Medicine, Atlanta, Georgia, USA

${ }^{2}$ Emory School of Medicine, Atlanta, Georgia, USA ${ }^{3}$ Department of Neurology, Emory School of Medicine, Atlanta, Georgia, USA ${ }^{4}$ Emory University, Atlanta, Georgia, USA

\section{Correspondence to Dr Faiz U Ahmad,} faiz.ahmad@emory.edu

Accepted 26 November 2015
CrossMark

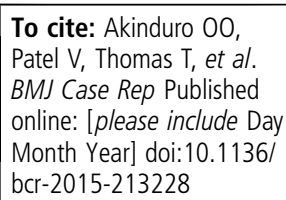

\section{DESCRIPTION}

First case: A 66-year-old woman presented to the emergency department (ED) with progressively worsening shortness of breath and mild swelling of her lips. Her home medications included simvastatin, lisinopril, esomeprazole, aspirin, metoprolol and hydrochlorothiazide. Soon after admission to the intensive case unit (ICU), she was given a single dose of lisinopril, which caused her lip swelling to worsen (figure 1A). She was started on methylprednisolone and diphenhydramine with no response. She was then given a dose of icatibant, a bradykinin $\mathrm{B}_{2}$ receptor antagonist, with complete resolution of the swelling within $24 \mathrm{~h}$ of administration (figure 1B).

Second case: A 39-year-old man was brought to the ED with altered mental status, and left-sided upper and lower extremity weakness. His medications prior to admission to the ICU were lisinopril, clonidine and furosemide. He was diagnosed with severe intracerebral haemorrhage and placed on nicardipine, levetiracetam and labetalol. On the fourth day of admission, he developed significant periorbital and tongue swelling (figure 2A). The tongue measured $7.9 \mathrm{~cm}$ from the left to right
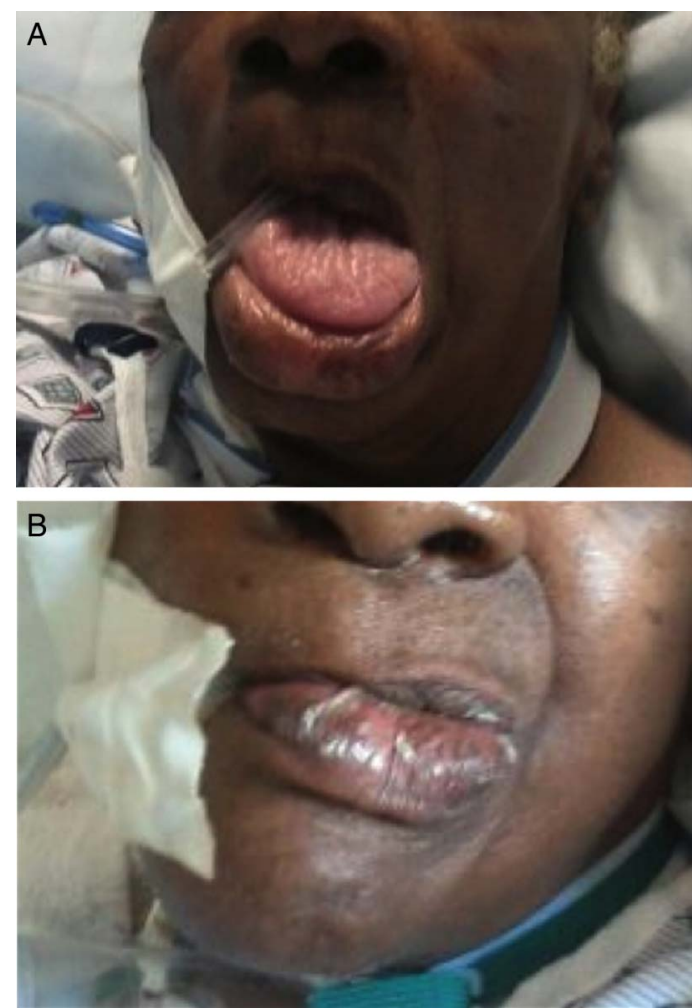

Figure 1 (A) Perioral and tongue swelling prior to administration of icatibant. (B) Decreased swelling of tongue and lips $24 \mathrm{~h}$ after administration of icatibant. borders and $3.3 \mathrm{~cm}$ from the superior to inferior borders. Nicardipine was discontinued and the patient was given an intravenous dosage of diphenhydramine with no subsequent improvement. $\mathrm{He}$ was given two doses of icatibant, with no improvement. Figure 2B depicts the tongue swelling after a lack of response to the icatibant. A diagnosis of idiopathic angio-oedema was made after complement levels were found to be normal, with no response to medical therapy. ${ }^{1}$ The swelling resolved within a month of discharge after no further treatment.

In these cases we highlight two different causes of angio-oedema, and the usefulness of the novel drug icatibant in their treatment. Angio-oedema can be categorised as allergic (IgE medicated) or nonallergic (bradykinin mediated). ${ }^{1}$ ACE inhibitor induced angio-oedema is bradykinin dependent, which probably explains why the first patient responded to icatibant while the second patient did
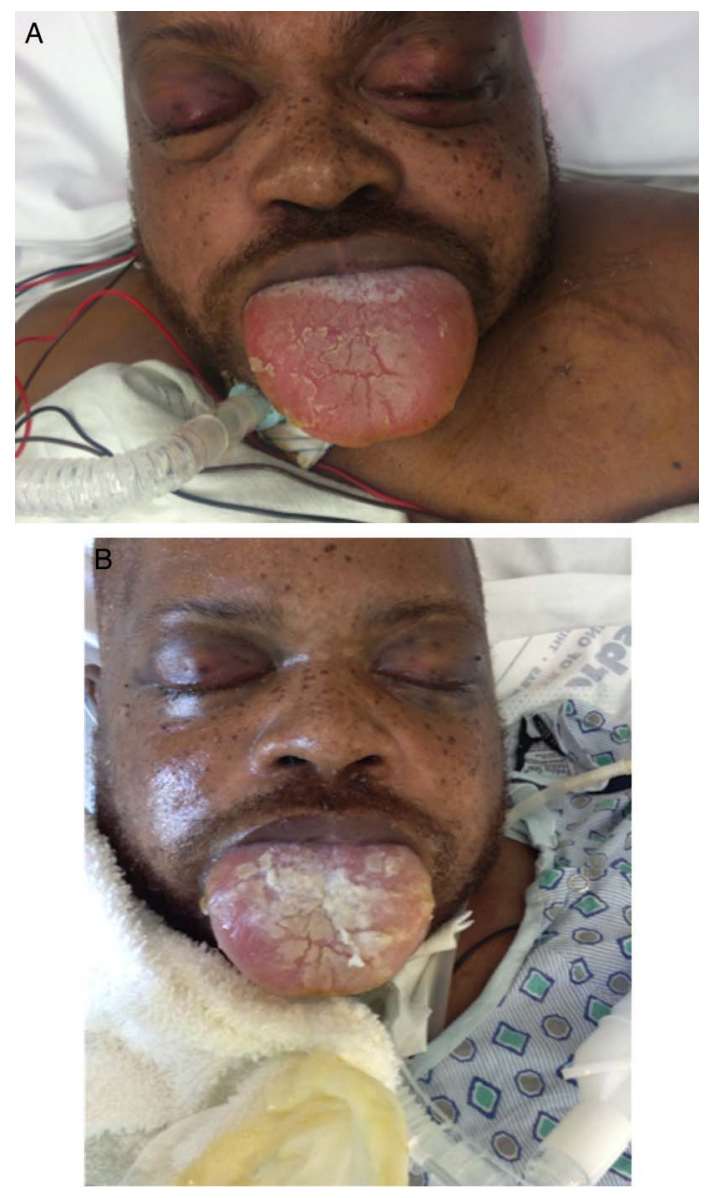

Figure 2 (A) Significant swelling of the tongue and periorbital region prior to administration of icatibant.

(B) Lack of response to icatibant therapy $48 \mathrm{~h}$ after administration of icatibant. 


\section{Images in...}

not. $^{2}$ Studies have shown icatibant efficacious in hereditary angio-oedema and ACE inhibitor-induced angio-oedema, but icatibant has not proven useful for allergic and idiopathic angio-oedema. ${ }^{3}$ Icatibant has no role in the prevention of future episodes, so patients with prior attacks of ACE inhibitor-induced angio-oedema should be sure to avoid ACE inhibitor drugs such as lisinopril, captopril, and enalapril. ${ }^{1}$ In these patients, no subsequent incidences of angio-oedema can be expected if ACE inhibitors are avoided. Patients with hereditary angio-oedema should avoid triggers for further episodes, such as stressful situations. ${ }^{3}$

Contributors $00 \mathrm{~A}$ contributed to writing and final editing of the manuscript. VP, TT contributed to final editing of the manuscript. FUA contributed to production of project idea and final editing of the manuscript.
Competing interests None declared.

Patient consent Obtained.

Provenance and peer review Not commissioned; externally peer reviewed.

\section{REFERENCES}

1 Baram M, Kommuri A, Sellers SA, et al. ACE inhibitor-induced angioedema. J Allergy Clin Immunol Prac 2013;1:442-5.

2 Lewis LM. Angioedema: etiology, pathophysiology, current and emerging therapies. J Emerg Med 2013;45:789-96.

3 Cole SW, Lundquist LM. Icatibant for the treatment of hereditary angioedema. Ann Pharmacother 2013;47:49-55.

Copyright 2015 BMJ Publishing Group. All rights reserved. For permission to reuse any of this content visit http://group.bmj.com/group/rights-licensing/permissions.

BMJ Case Report Fellows may re-use this article for personal use and teaching without any further permission.

Become a Fellow of BMJ Case Reports today and you can:

- Submit as many cases as you like

- Enjoy fast sympathetic peer review and rapid publication of accepted articles

- Access all the published articles

- Re-use any of the published material for personal use and teaching without further permission

For information on Institutional Fellowships contact consortiasales@bmjgroup.com

Visit casereports.bmj.com for more articles like this and to become a Fellow 